\title{
Signet Ring Cell Lymphoma with Plasmacytic Differentiation in a Pig
}

\author{
Sumie NISHIJO ${ }^{1)}$, Kikumi OGIHARA ${ }^{2)}$, Yoshiharu ISHIKAWA ${ }^{3)}$ and Koichi KADOTA ${ }^{3) *}$ \\ 1) Yokohama City Meat Inspection Center, 3-53 Daikoku, Tsurumi, Yokohama, Kanagawa 230-0053, Japan \\ 2) Department of Pathology, Azabu University, 1-17-7 Fuchinobe, Sagamihara, Kanagawa 229-8501, Japan \\ ${ }^{3)}$ Hokkaido Research Station, National Institute of Animal Health, 4 Hitsujigaoka, Toyohira, Sapporo, Hokkaido 062-0045, Japan
}

(Received 26 October 2012/Accepted 28 December 2012/Published online in J-STAGE 18 January 2013)

ABSTRACT. A case of signet ring cell lymphoma in a 3-year-old mixed-breed sow is described. Macroscopical examination revealed enlargement of superficial, thoracic and abdominal lymph nodes and multiple tumor masses in the liver. The neoplastic tissue was composed of follicle center-like structures, in which neoplastic cells with Russell bodies were conspicuous. The bodies were immunostained for IgM ( $\kappa$ ), and corresponded to moderately dense amorphous material within markedly distended cisternae of rough endoplasmic reticulum (RER) at the ultrastructural level. In contrast to typical signet ring cell lymphoma, the component cells of which resemble follicular center B lymphocytes with poorly developed RER, most neoplastic cells had features of plasma cells characterized by a cartwheel arrangement of heterochromatin and development of RER. Signet ring cells frequently had one or a few large Russell bodies occupying the entire cytoplasm, which may have been caused by abundant synthesis and defective secretion of immunoglobulin.

KEY WORDS: follicular lymphoma, Russell body, signet ring cell, swine, tumor.

doi: 10.1292/jvms.12-0469; J. Vet. Med. Sci. 75(6): 799-802, 2013

In humans, follicular lymphoma is characterized by formation of follicle center-like structures by tumor cells, and its normal counterpart is follicular center B lymphocytes (centroblasts and centrocytes) [18]. There are several cytological variants of this lymphoma. The signet ring cell variant is composed partly or entirely of signet ring cells with the nuclei displaced to one side by a clear vacuole (clear vacuole type) or eosinophilic PAS-positive globules (Russell body type) [3]. Follicular plasmacytoma or follicular lymphoma with plasmacytic differentiation is another variant in which the neoplastic follicle centers consist predominantly of plasma cells [3]. Neoplastic cells with Russell bodies may be observed in diffuse lymphomas, such as lymphoplasmacytic lymphoma and lymphoplasmacytoid lymphoma [3, 14]. Canine and ferret lymphomas with Russell body inclusions are considered to be a unique histological type and are designated "lymphoma with Mott cell differentiation" [7, 13]. Marginal zone B cells are suggested as their presumed normal counterparts, but neither histological nor immunohistochemical evidence has been presented [4].

Unlike in cattle [9], follicular lymphoma is not infrequent in swine and usually occurs in adult animals $[16,17]$. A case of signet ring cell lymphoma, which consisted of follicle center cells, has been reported in a 4-year-old sow [11]. These neoplastic cells often showed morula cell or grape cell morphology. Here, we report a swine signet ring cell lymphoma with plasmacytic differentiation in which one or a few large Russell bodies occupied the entire cytoplasm.

*Correspondence to: Kadota, K., Hokkaido Research Station, National Institute of Animal Health, 4 Hitsujigaoka, Toyohira, Sapporo, Hokkaido 062-0045, Japan.

e-mail: kkadota@affrc.go.jp

(C)2013 The Japanese Society of Veterinary Science
A 3-year-old mixed-breed sow was brought to an abattoir in an apparently healthy state. At necropsy, the mesenteric, hepatic and cervical (up to $11 \times 4.5 \times 3 \mathrm{~cm}$ ) lymph nodes were markedly enlarged, and the cut surfaces were milkywhite, homogeneous, solid and partially hemorrhagic. Similar cut surfaces and moderate enlargement were observed in the parotid, mandibular, subiliac, inguinal, popliteal, bronchial, splenic, renal and internal iliac (up to $16 \times 7 \times 3 \mathrm{~cm}$ ) lymph nodes. On the surface of the liver, there were multiple white to milky-white, round masses, 4 to $0.8 \mathrm{~cm}$ in diameter, some of which bulged out from the capsule. Similar masses were also seen in the parenchyma. The spleen was greatly enlarged with bulging cut surfaces and prominent lymphoid follicles. No abnormal findings were detected in the spinal bone marrow.

Tissue samples were fixed in $10 \%$ buffered formalin, embedded in paraffin, sectioned at $4 \mu \mathrm{m}$ and stained with hematoxylin and eosin (HE), Giemsa and periodic acid-Schiff (PAS). Immunohistochemistry was performed on paraffin sections. The streptavidin-biotin-peroxidase complex (SAB) labeling method with SAB kits (Nichirei, Tokyo, Japan) was used. The primary reagents employed were rabbit polyclonal antibodies to human CD3 (Dako, Glostrup, Denmark), human CD5 (Lab Vision, Fremont, CA, U.S.A.), swine IgM ( $\mu$-chain specific) (Bethyl Laboratories, Montgomery, TX, U.S.A.), swine IgA ( $\alpha$-chain specific) (Bethyl), human $\lambda$-light chain (BioGenex Laboratories, San Ramon, CA, U.S.A.) and human $\kappa$-light chain (BioGenex). In addition, goat polyclonal antibody to swine IgG (Fc specific) (Bethyl) and mouse monoclonal antibody to human CD79a (Dako) were also used. For comparison, a published case of signet ring cell lymphoma [11] was investigated in the same manner as a control case. Small pieces of formalin-fixed tissues were post-fixed in $1 \%$ osmium tetroxide and embedded in epoxy resin. Ultrathin sections were stained with uranyl acetate and 

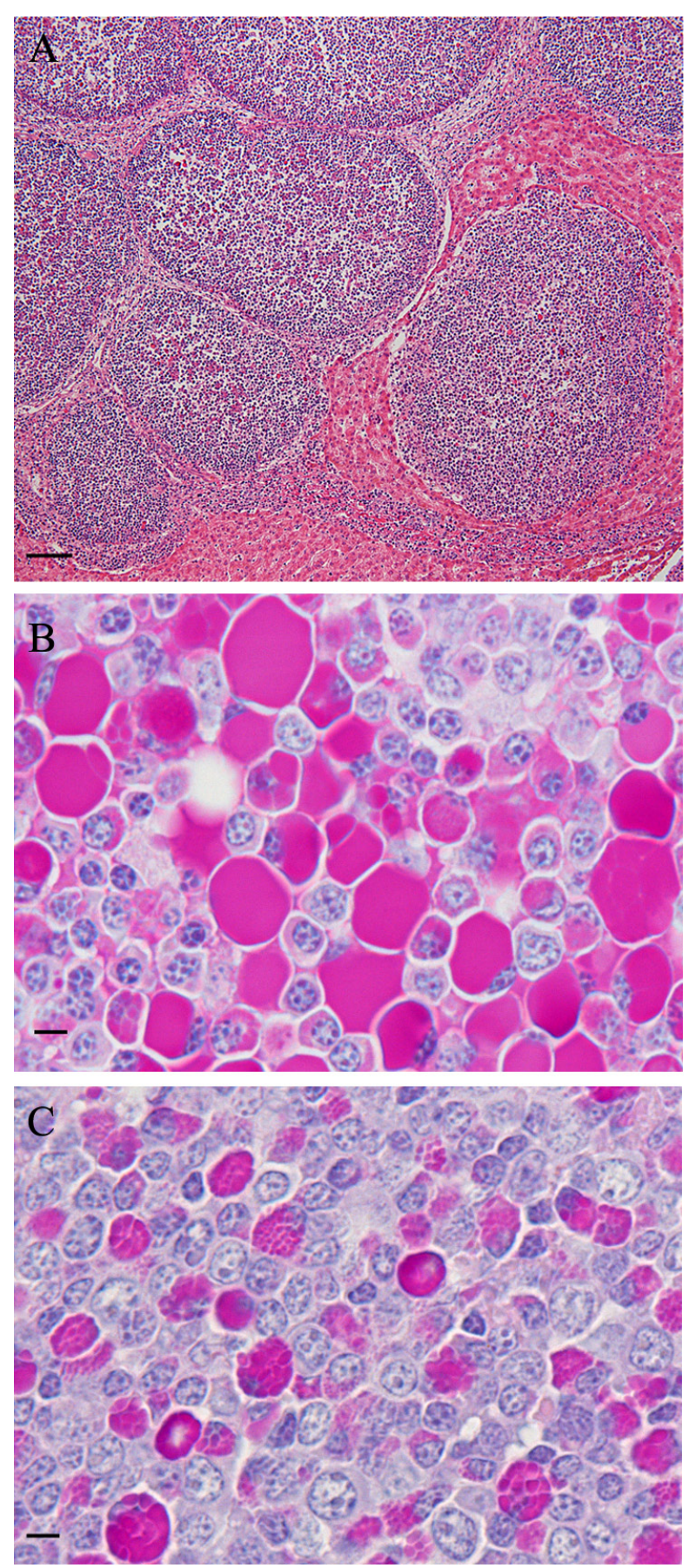

Fig. 1. Histology of neoplastic tissues or cells. (A) Liver. Follicle center-like structures are visible, and one of them appears to be intralobular (lower right). HE. Bar $=100 \mu \mathrm{m}$. (B) Internal iliac lymph node. Most positive neoplastic cells contain one or a few large pink globules. PAS. Bar $=5 \mu \mathrm{m}$. (C) Control case, superficial cervical lymph node. Positive neoplastic cells with several to many pink globules show a morula cell morphology. PAS. Bar $=5$ $\mu \mathrm{m}$.
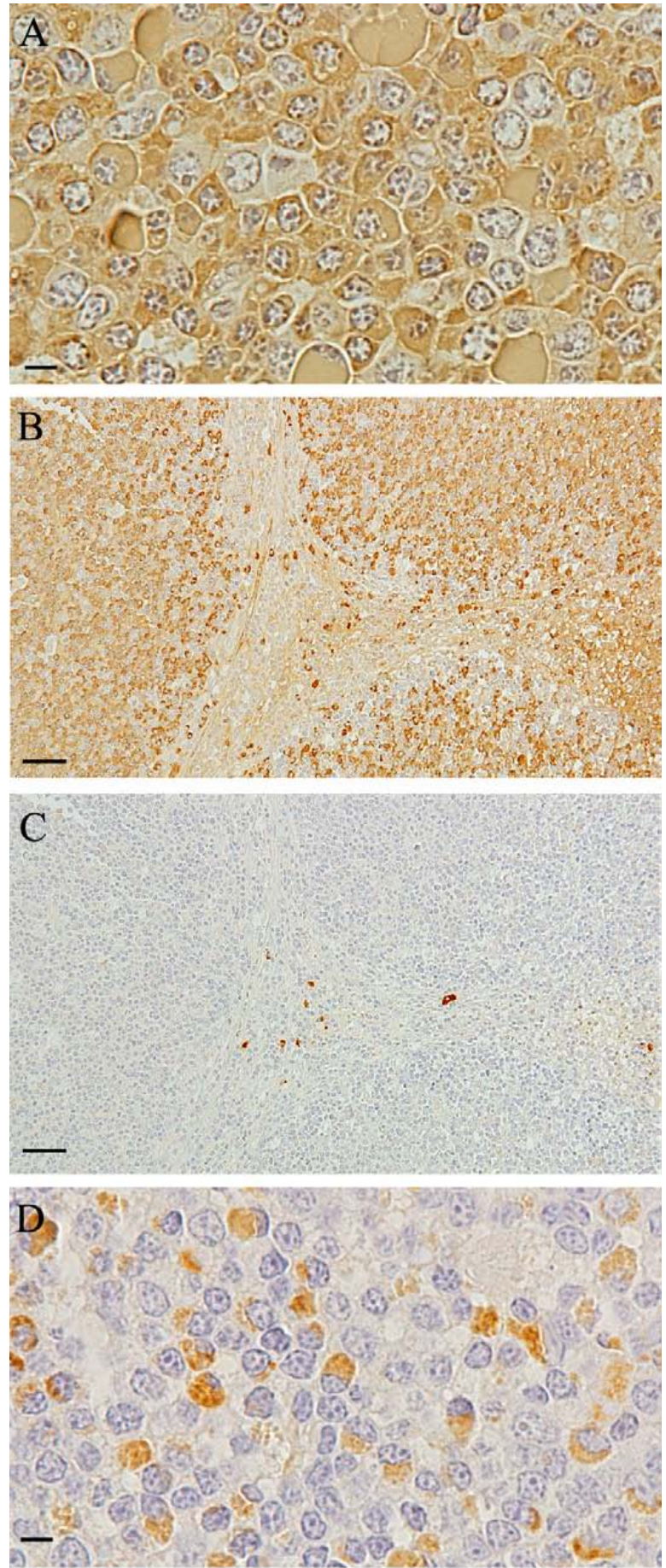

Fig. 2. Immunohistochemistry of neoplastic cells. (A) Internal iliac lymph node. Plasmacytoid cells are positive for $\kappa$ light chain, irrespective of the presence of intracytoplasmic globules. $\mathrm{SAB}$. Bar $=5 \mu \mathrm{m}$. (B) Internal iliac lymph node. A large number of $\kappa$-positive neoplastic cells are seen within follicle center-like structures. SAB. Bar $=40 \mu \mathrm{m}$. (C) Internal iliac lymph node. Adjacent section shows the same structures as those in (B), but $\lambda$-positive cells are rare and observed in the interfollicular tissue. SAB. Bar $=40 \mu \mathrm{m}$. (D) Control case, superficial cervical lymph node. Lymphoid cells with Russell bodies stain positively for $\lambda$ light chain. SAB. Bar $=5 \mu \mathrm{m}$. 
lead citrate, and examined by electron microscopy (EM).

Histologically, in the lymph nodes examined, the normal architecture was completely effaced by neoplastic tissue, which was composed of follicle center-like structures. Similar structures were also observed in the liver (Fig. 1A). No normal lymphatic follicles were detected in the spleen. The white pulp was replaced by accumulations of several follicle center-like structures, which extended into the surrounding red pulp. Most tumor cells had eccentric round to oval nuclei with a cartwheel pattern of heterochromatin and small- to medium-sized nucleoli. The cytoplasm was abundant, and frequent cells contained one or a few large eosinophilic globules that were PAS positive, though cells with many globules were also present (Fig. 1B). Other neoplastic cells resembled centroblasts or centrocytes. Mitotic figures (7-15 per high-power field) were observed. Follicular dendritic cells were sparsely distributed, but macrophages were rare. In the control case, neoplastic cells with eosinophilic globules were smaller in size than those in the current case (Fig. $1 \mathrm{C})$, and cells with one or few globules were extremely rare.

Immunohistochemically, the neoplastic cells showed reactivity for CD79a, and the majority were plasmacytoid and positive for $\mu$ and $\kappa$ chains (Fig. 2A and 2B). There were $\lambda$-positive plasma cells and CD3-positive lymphocytes in the interfollicular tissues (Fig. 2C). Only lymphoma cells with globules expressed $\mu$ and $\lambda$ chains in the previous case (Fig. 2D).

Ultrastructurally, plasmacytoid cells had nuclei with a cartwheel arrangement of heterochromatin and slightly- to well-developed rough endoplasmic reticulum (RER) (Fig. $3 \mathrm{~A})$. In some cells, the well-developed RER displayed dilated cisternae containing homogeneous material of moderate electron density. There were transitional forms between these cells and cells whose cytoplasm was filled with single cisternae of RER (Fig. 3B). Well-developed and diffusely or focally dilated RER appeared to have coalesced with dissolution of cisternal membranes. Lymphoid cells were characterized by less condensed chromatin and less developed RER.

Follicular lymphoma is a tumor of cells capable of forming follicle center-like structures, which may be observed in sites where lymphatic follicles are normally absent [11]. In the current case, follicle center-like structures were observed throughout the affected lymph nodes, and also in the liver. Such findings supported the diagnosis of follicular lymphoma. Although follicle centers may be preferentially invaded by neoplastic cells in diffuse centroblastic lymphoma [10, 17], this is interpreted as showing homing into pre-existing follicle centers, but not forming neoplastic ones de novo.

As in the previously reported case [11], a significant proportion of neoplastic cells contained IgM-positive globules (Russell body type) in the present lymphoma. However, most tumor cells had plasma cell features, such as eccentrically located nuclei, cartwheel distribution of heterochromatin and variously developed RER. Follicular lymphoma with plasmacytic differentiation is a cytological variant of follicular lymphoma in humans and is distinct from typical follicular lymphoma or signet ring cell lymphoma composed

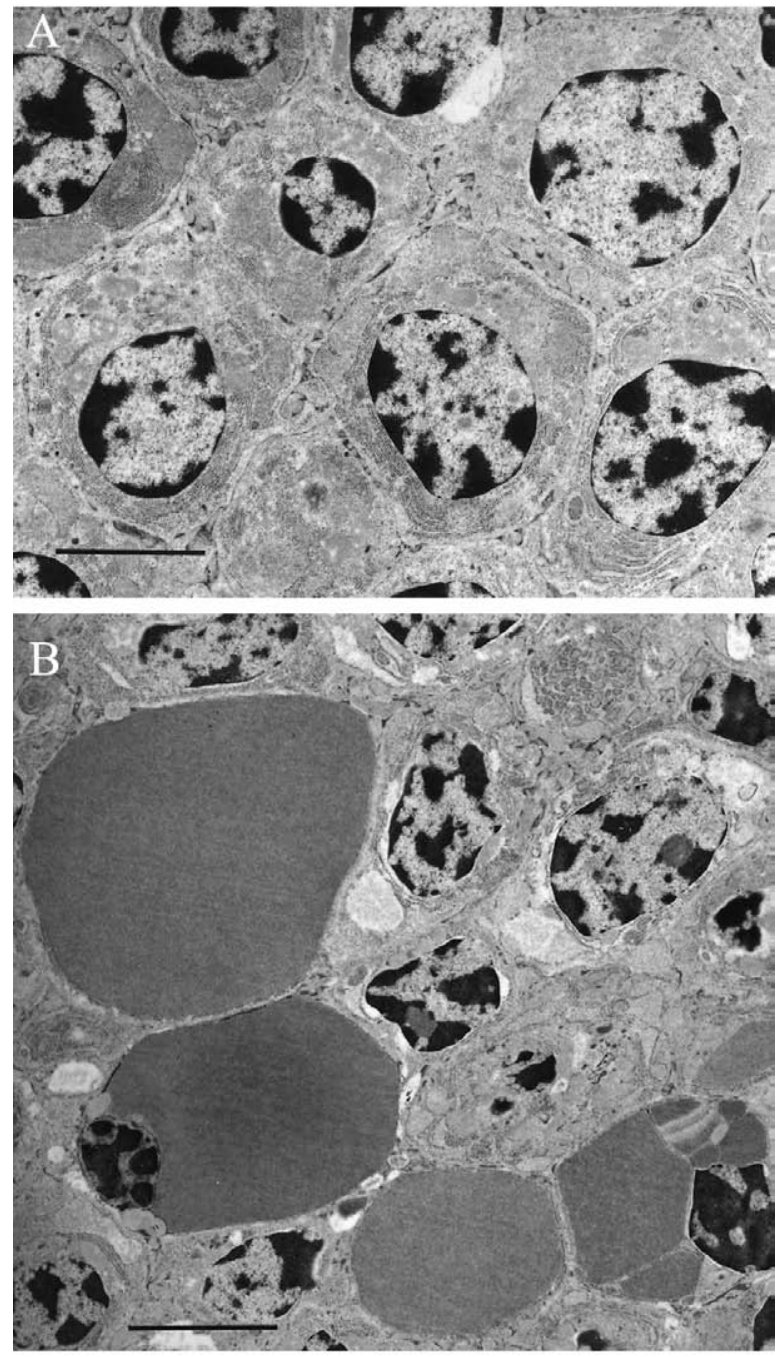

Fig. 3. Ultrastructure of neoplastic cells. (A) Internal iliac lymph node. Plasmacytoid cells contain parallel lamellae of RER, and one has concentrically arranged or focally dilated cisternae of RER (upper left). EM. Bar $=4 \mu \mathrm{m}$. (B) Internal iliac lymph node. Highly expanded cisternae of RER with homogeneous contents occupy almost all of the cytoplasm in some plasmacytoid cells. EM. Bar $=5 \mu \mathrm{m}$.

of follicle center cells $[3,18]$. Taking these considerations into account, a final diagnosis of signet ring cell lymphoma with plasmacytic differentiation was made. Similar differentiation has been observed in a feline lymphoma of germinal center origin, which was composed exclusively of IgMproducing immunoblastoid or plasmacytoid cells [5].

In the previous case, neoplastic cells with Russell bodies showed morula cell or grape cell morphology [11]. Because the RER was poorly developed and showed focal dilatation of the cisternae, the neoplastic cells were considered to be defective in immunoglobulin secretion [1]. In the present case, in contrast, frequent signet ring cells contained one or a few large globules, as observed by light microscopy, and the 
well-developed and dilated RER appeared to have coalesced with dissolution of cisternal membranes. Such findings indicate that not only the disordered secretory mechanism but also abundant production of immunoglobulin [6] is responsible for the formation of large Russell bodies. Similar globules have been observed in plasmacytoid cells in a swine lymphoplasmacytic lymphoma [8]. It should be noted that there are differences in the size and number of Russell bodies between lymphoid cells and plasmacytoid cells in swine lymphoid neoplasms. Likewise, Russell bodies in human signet ring cell lymphoma [14] tend to be smaller in size and larger in number than those in lymphomas, such as lymphoplasmacytic lymphoma, lymphoplasmacytoid lymphoma and diffuse large B cell lymphoma with plasma cell differentiation $[3,14]$.

In a study of canine Ig-producing tumors, the majority were found to be positive for $\lambda$ chain [2], and this is a reflection of the fact that there are far more $\lambda$-positive than $\kappa$-positive cells in normal tissues [12]. In contrast, such an imbalance in the $\kappa / \lambda$ ratio is absent in swine [2], suggesting a similar frequency of $\kappa$ - and $\lambda$-producing tumors. In studies on relatively small numbers of cases, however, the proportion of the tumors may incline one or the other way by chance $[17,19]$. As shown in the present study, it is very easy to demonstrate the monoclonality of swine Ig-producing tumors based on light chain restriction. Lymphoid malignancies may differ in various parameters among animal species $[15,17]$, and follicular lymphoma in swine [17] is cytologically more similar to human cases [14] than that in cattle [9].

\section{REFERENCES}

1. Alanen, A., Pira, U., Lassila, O., Roth, J. and Franklin, R. M. 1985. Mott cells are plasma cells defective in immunoglobulin secretion. Eur. J. Immunol. 15: 235-242. [Medline] [CrossRef]

2. Breuer, W., Colbatzky, F., Platz, S. and Hermanns, W. 1993. Immunoglobulin-producing tumours in dogs and cats. J. Comp. Pathol. 109: 203-216. [Medline] [CrossRef]

3. Chan, J. K. C. 2007. Tumors of the lymphoreticular system. pp. 1139-1288. In: Diagnostic Histopathology of Tumors, 3rd ed. (Fletcher, C. D. M. ed.), Churchill Livingstone, London.

4. De Zan, G., Zappulli, V., Cavicchioli, L., Di Martino, L., Ros, E., Conforto, G. and Castagnaro, M. 2009. Gastric B-cell lymphoma with Mott cell differentiation in a dog. J. Vet. Diagn. Invest. 21: 715-719. [Medline] [CrossRef]

5. Ezura, K., Ezura, K., Nomura, I., Ishikawa, Y. and Kadota, K. 2007. Immunoblastic lymphoma of germinal center origin in a cat. Can. Vet. J. 48: 211-213. [Medline]
6. Ghadially, F. N. 1997. Endoplasmic reticulum. pp. 433-602. In: Ultrastructural Pathology of the Cell and Matrix, 4th ed., Butterworth-Heinemann, Boston.

7. Gupta, A., Gumber, S., Schnellbacher, R., Bauer, R. W. and Gaunt, S. D. 2010. Malignant B-cell lymphoma with Mott cell differentiation in a ferret (Mustela putoius furo). J. Vet. Diagn. Invest. 22: 469-473. [Medline] [CrossRef]

8. Hoshino, M., Oguro, M., Tanabe, J., Tsujisawa, M., Tosaka, Y., Shibahara, T. and Kadota, K. 2006. Immunohistochemical investigation of six cases of swine lymphoma. J. Jpn. Vet. Med. Assoc. 59: 135-139 (in Japanese with English summary).

9. Ishino, S., Kadota, K., Yoshino, T. and Yamamoto, H. 1990. Pathological and immunohistochemical studies of follicular lymphoma in two calves. J. Comp. Pathol. 103: 265-275. [Medline] [CrossRef]

10. Kadota, K. and Nakajima, H. 1988. Histological progression of follicular centre cell lymphomas to immunoglobulin-producing tumours in two pigs. J. Comp. Pathol. 99: 145-158. [Medline] [CrossRef]

11. Kadota, K. and Niibori, S. 1985. A case of swine follicular lymphoma with intracytoplasmic immunoglobulin inclusions. $J$. Comp. Pathol. 95: 599-608. [Medline] [CrossRef]

12. Kawaoka, Y. and Naiki, M. 1981. Chemical structure of immunoglobulins. pp. 201-241. In: Immunology in Veterinary Science (Izawa, H., Shimizu, Y., Naiki, M. and Mikami, T. eds.), Kindai Shuppan, Tokyo (in Japanese).

13. Kodama, A., Sakai, H., Kobayashi, K., Mori, T., Maruo, K., Kudo, T., Yanai, T. and Masegi, T. 2008. B-cell intestinal lymphoma with Mott cell differentiation in a 1-year-old miniature Dachshund. Vet. Clin. Pathol. 37: 409-415. [Medline] [CrossRef]

14. Lennert, K. and Feller, A. C. 1992. B-cell lymphomas. pp. 53-163. In: Histopathology of Non-Hodgkin's Lymphomas, 2nd ed., Springer-Verlag, Berlin.

15. Murayama, S., Sato, K., Ikehata, T., Wada, Y., Ishikawa, Y. and Kadota, K. 2011. Cytologic and immunophenotypic investigation of lymphohematopoietic neoplasms in cattle. Jpn. Agric. Res. Q. 45: 225-231. [CrossRef]

16. Nakajima, H., Kasai, K., Kadota, K. and Ishino, S. 2000. Swine lymphoma: histological characterization and classification. $J$. Jpn. Vet. Med. Assoc. 53: 324-327 (in Japanese with English summary).

17. Ogihara, K., Ohba, T., Takai, H., Ishikawa, Y. and Kadota, K. 2012. Lymphoid neoplasms in swine. J. Vet. Med. Sci. 74: 149-154. [Medline] [CrossRef]

18. Shibuya, A., Takahama, M. and Katayama, I. 1984. Signet ring cell lymphoma, Russell body cell IgM type. Case report. Nihon Ketsueki Gakkai Zasshi 47: 107-112. [Medline]

19. Tanimoto, T., Minami, A., Yano, S. and Ohtsuki, Y. 1994. Ileal lymphoma in swine. Vet. Pathol. 31: 629-636. [Medline] [CrossRef] 